\title{
A Distinctive Large Breeding Population of Ringed Seals (Phoca hispida) Inhabiting the Baffin Bay Pack Ice
}

\author{
K.J. FINLEY' ${ }^{1}$, G.W. MILLER ${ }^{1}$, R.A. DAVIS' ${ }^{\text {and W.R. KOSKI }}{ }^{1}$
}

\begin{abstract}
Aerial surveys in June and July, 1978 and 1979, documented an unexpectedly large population (at least 417 000) of ringed seals, some with pups, inhabiting the pack ice of Baffin Bay. Pack-ice seals are smaller than their fast-ice counterparts and have a different diet and gut parasite load. Age and reproductive data, although limited, indicate that the offshore seals are a normal breeding population. Pack-ice seals probably mix with fast-ice seals in coastal areas during the brief open-water season but morphological and ecological differences suggest that the populations are reproductively isolated. This study prompts reconsideration of the importance of offshore pack ice to ringed seals and, therefore, to the coastal hunting economy of Inuit in Greenland and Baffin Island.
\end{abstract}

Key words: ringed seals, Baffin Bay, pack ice, distribution, population discreteness, management

RÉSUMÉ. Des inventaires aériens effectués en juin et juillet, 1978 et 1979, ont documenté une population importante d'au moins 417000 phoques annelés, certains accompagnés de jeunes, habitant le pack de la baie Baffin. Les phoques du pack sont plus petits que ceux de la banquise côtière et ont un régime alimentaire et des parasites intestinaux différents. Des données sur l'âge et le reproduction, quoique limitées, indiquent que les phoques au large des côtes suivent un cycle de reproduction normal. Les phoques du pack se mêlent probablement à ceux de la banquise dans les régions côtières durant la brève saison d'eau libre mais les différences morphologiques et écologiques suggèrent que les populations se reproduisent peut-être indépendamment l'une de l'autre. La présente étude encourage une reconsidération de l'importance du pack chez les phoques annelés et ainsi, de son importance dans l'économie côtière des Inuit chasseurs du Groenland et de l'île de Baffin.

Mots clés: phoque annelés, baie Baffin, banquise, distribution, isolation reproductrice de la population, contrôle de la population

Traduit pour le journal par Maurice Guibord.

\section{INTRODUCTION}

The life of the ringed seal (Phoca hispida) is intimately related to the dynamics of sea ice. The circumpolar distribution of the ringed seal is attributed to its ability to maintain breathing holes in solid ice - a unique adaptation that allows it to occupy large areas of the arctic seas that are inaccessible to most marine mammals during much of the year.

Like most phocid seals, the ringed seal uses sea ice as a platform on which to give birth and suckle its young. McLaren (1958a) hypothesized that stable ice in March-April was critical to pupping success, and that the species therefore preferred complex coastal areas where the ice was most stable. He believed that population size was limited by the amount of suitable fast ice. Immature seals were thought to be excluded from the preferred breeding habitat and to occupy areas of unstable ice. Subsequent accounts have also emphasized the significance of stable fast ice in the life history and population dynamics of this species (McLaren, 1961, 1962, 1966a; Smith, 1973, 1975; Smith and Stirling, 1975; Stirling and Smith, 1977; Finley, 1979; Burns et al., 1981).

Nonetheless, ringed seals do not necessarily depend only on fast ice as preferred breeding habitat. Fedoseev and Yablokov (1964) recognized, on morphometric evidence, a distinctive ringed seal that inhabited and reproduced on the pack-ice fields of the Sea of Okhotsk. Fedoseev (1975) later recognized two basic 'ecotypes' of $\boldsymbol{P}$. hispida in eastern Siberian waters seals of the fast ice and of the pack ice. He concluded that seals of the pack ice were smaller, grew relatively faster and matured earlier than did seals of the fast ice.
As part of the Eastern Arctic Marine Environmental Studies program (Sutterlin and Snow, 1982) extensive aerial surveys were undertaken during 1978 and 1979 to document the distribution and abundance of marine mammals and birds in NW Baffin Bay. In May and June 1978 we saw unexpectedly large numbers of ringed seals, some with pups, in the offshore pack ice of Baffin Bay. In 1979 the study was expanded in order to better define the status of the offshore seals. We attempted to determine whether seals on pack ice were predominantly nonbreeding subadults as implied by McLaren (1958a) and Smith (1973), or a breeding population such as occurs in the Sea of Okhotsk. This question was addressed with: 1) aerial surveys to assess relative numbers and distribution, 2) specimen collections on the pack ice to determine age and reproductive status, and 3) morphological and biochemical comparisons of animals collected on offshore pack ice and coastal fast ice. We also examined the diets, stomach parasites and development of moult of pack-ice and fast-ice seals.

\section{METHODS}

\section{Study Area and Ice Conditions}

The study area encompassed the coastal waters of NE Baffin Island from Lancaster Sound south to Clyde and adjacent offshore waters of Baffin Bay (Fig. 1). Baffin Bay forms a deep (500-2400 m), enclosed depression between Baffin Island and Greenland. The basin is dominated by cold arctic waters of the southward-flowing Baffin Current along the western side of Baffin Bay, and an intrusion of cold Atlantic water, the West 
Greenland Current, on the eastern side of Baffin Bay (Collin and Dunbar, 1964; Fissel et al., 1982). The physiography, oceanography and climate of Baffin Bay interact to produce a seasonal ice sheet that has a predictable degree of organization.
Freeze-up occurs rapidly in fiords during October leaving characteristically smooth ice. During early winter the fast ice extends in a shelf $30-50 \mathrm{~km}$ wide along eastern Baffin Island, anchored in part by numerous stranded icebergs, and fluctuating in extent depending on prevailing winds. In June 1979,

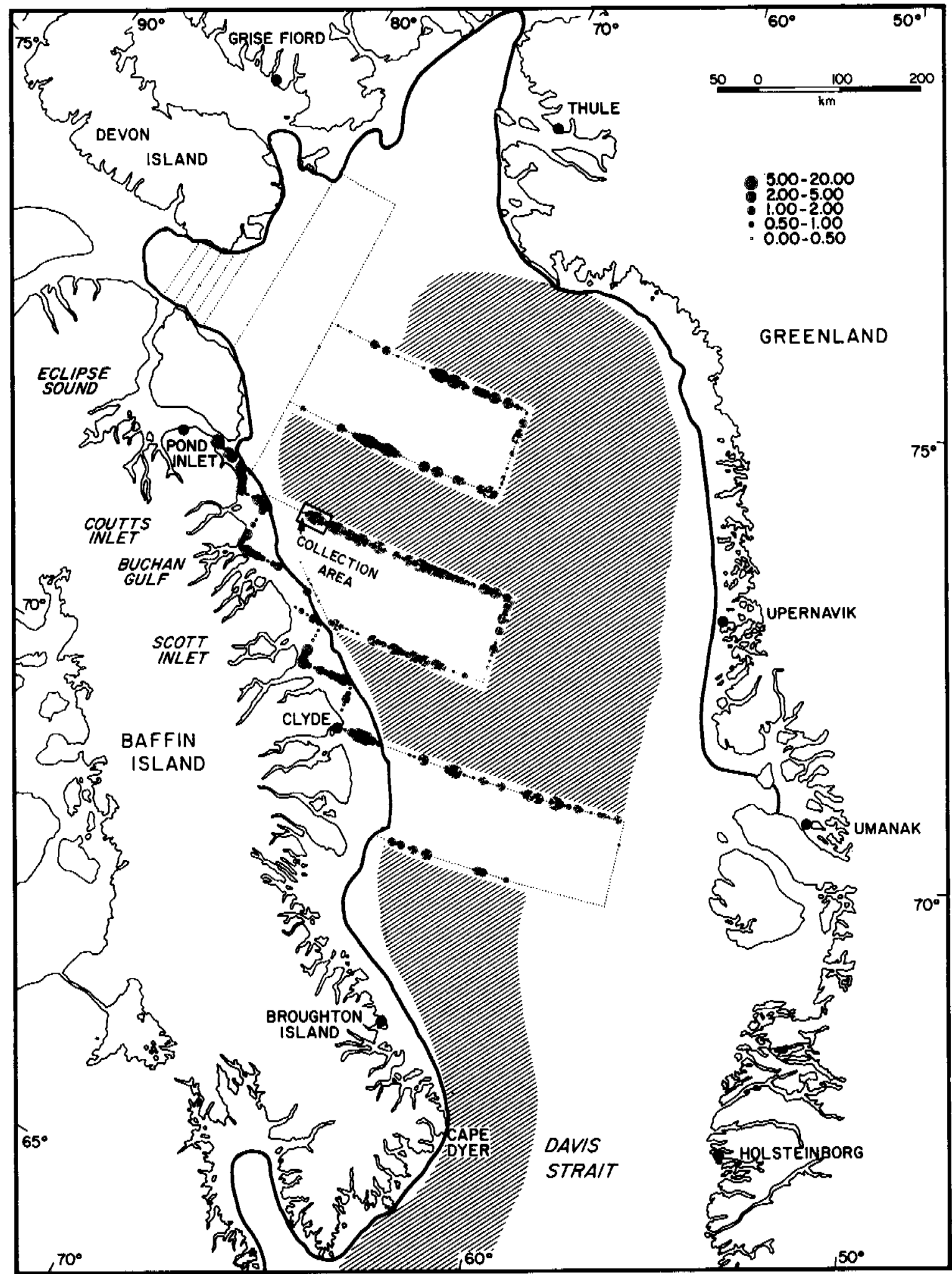

FIG. 1. The Baffin Bay area showing the extent of pack ice (hatched area) of $>75 \%$ cover and the survey routes (dotted lines) flown repeatedly in 1979. The solid line indicates the edge of the landfast ice (from NOAA imagery, June 1979). Symbols are densities (seals $\mathrm{km}^{-2}$ ) in 2-min segments of transects. The collection area for pack-ice seals is shown. 
this shelf between Cape Dyer and Pond Inlet covered an area of about $20000 \mathrm{~km}^{2}$ (Fig. 1). Within the same area the fiord ice is constant at about $16000 \mathrm{~km}^{2}$ and remains solid (landfast) from October until July. The fiord complex of Pond Inlet, Eclipse Sound and Navy Board Inlet has an additional 8000 $\mathrm{km}^{2}$ of fast ice.

At its maximum extent in March, the pack ice covers most of Baffin Bay. The ice in western Baffin Bay continually drifts southward, and in spring the first area of open water, the 'North Water', appears along the northern periphery of the ice fields (Fig. 2). In late June 1979, close pack ice (>75\% cover) covered about $300000 \mathrm{~km}^{2}$ of Baffin Bay (Fig. 1). Extensive pack ice, known as the 'Middle Ice' to nineteenth- century whalers (cf. Markham, 1874), persists into August on the west side of Baffin Bay. In 1979, Baffin Bay was ice-free by late August but by mid-October new ice was beginning to develop.

\section{Aerial Surveys}

In 1978 and 1979 extensive aerial surveys were conducted in NW Baffin Bay and Lancaster Sound from early May to midJuly. These surveys were designed to document the distribution and abundance of marine mammals and seabirds as part of the Eastern Arctic Marine Environmental Studies (EAMES) program (Sutterlin and Snow, 1982). Because of the large

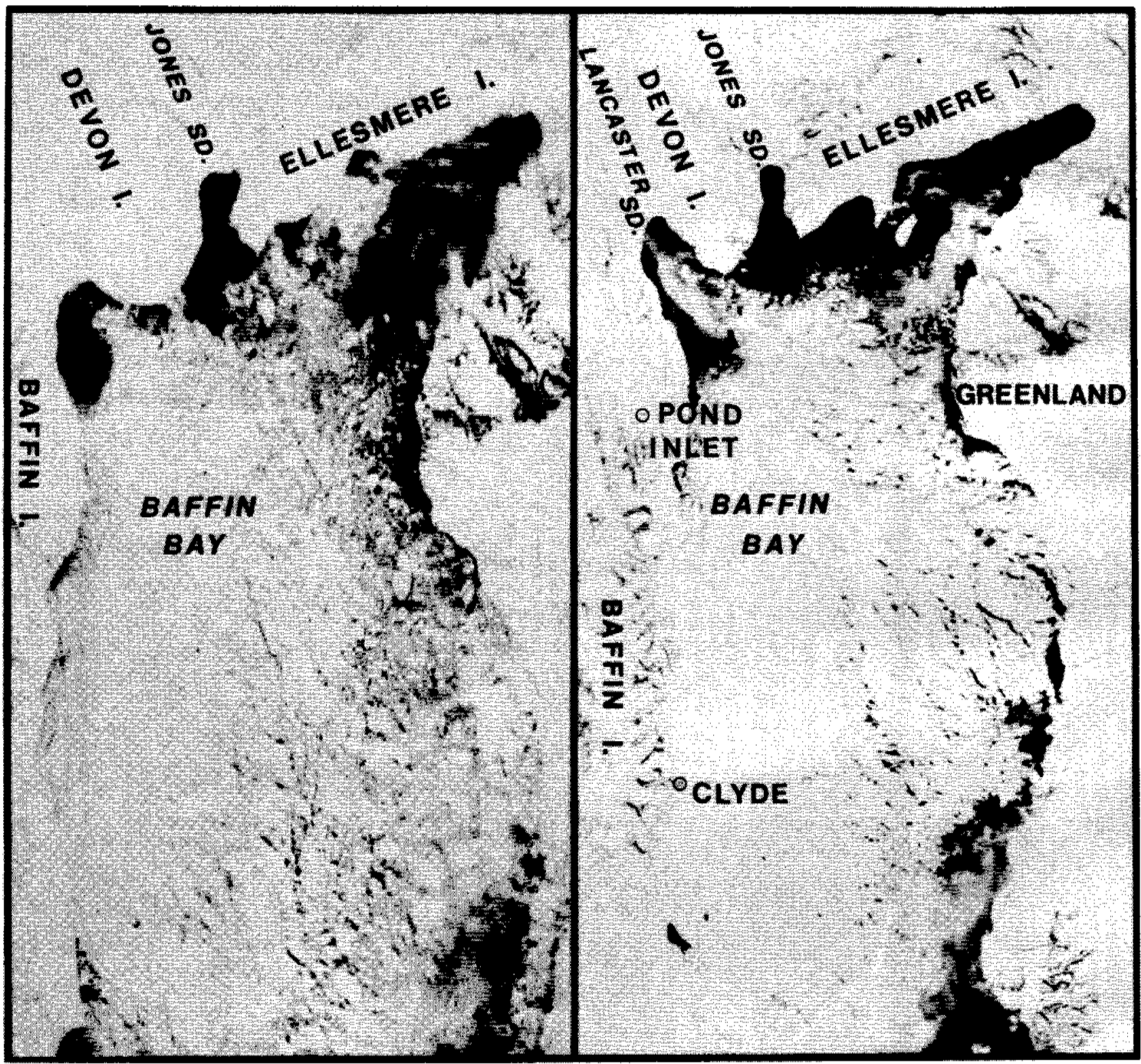

FIG. 2. Synoptic view of ice cover in Baffin Bay on 25 May, 1978 and 1979. Note the clearing of pack ice from the northern periphery of the fast ice leav ing a large area of open water, the North Water. 
survey area and associated logistic costs, both birds and mammals were counted during low-level $(45 \mathrm{~m})$ surveys with a transect width of $400 \mathrm{~m}$. While this technique is adequate for describing the distribution of marine mammals, the low altitude and narrow transect strip are generally of limited value in quantitative evaluations of density, especially of seals that are hauled out on the ice. Thus, in addition to the low-level surveys, we conducted special surveys at $90 \mathrm{~m}$ with an $800-\mathrm{m}$ transect width in order to provide density estimates of ringed seals during late June and early July. These surveys were conducted over the fast ice of fiords in NE Baffin Island in 1978, and over the adjacent shelf of fast ice and the pack ice in 1979.

All surveys were conducted in a DeHavilland DHC-6 Twin Otter with one observer in the right front seat and another on the left in the second seat behind the pilot. During surveys at 45 and $90 \mathrm{~m}$, airspeeds were approximately 185 and 240 $\mathrm{km} \cdot \mathrm{h}^{-1}$, respectively. Survey altitude was maintained by radar altimeter, and accurate navigation in offshore areas was provided by a Global Navigation System (GNS-500).

Survey routes were divided into transects of lengths 18-140 $\mathrm{km}$; most offshore transects were $56-111 \mathrm{~km}$ long. Each transect was subdivided into 2 -min segments $(6.2 \mathrm{~km}$ at 185 $\mathrm{km} \cdot \mathrm{h}^{-1}$ and $8.0 \mathrm{~km}$ at $\left.240 \mathrm{~km} \cdot \mathrm{h}^{-1}\right)$. The observers dictated information concerning transects, seals, visibility and ice conditions into audio recorders. These data were later transcribed, keypunched, and keyverified for computer tabulation, analysis, and mapping. Computer-produced maps were based on the density of seals recorded in each 2-min transect segment. Additional details on survey design and analyses are given in Koski and Davis (1979) and Koski (1980).

\section{Population Estimation and Correction Factors}

Only high-level $(90 \mathrm{~m}$ ) surveys during the peak of the haulout season were used in estimating population sizes. Densities were obtained from three ice types - fiord, coastal shelf and pack ice - and then extrapolated to the total area of each ice type. Coverage with $45-\mathrm{m}$ surveys indicated that extrapolation of densities in a particular ice type was reasonable given the wide and rather uniform distribution of seals. The population estimates are conservative since they do not account for seals that were not hauled out during the surveys. To the extent possible, this source of underestimation was minimized by conducting the surveys during the peak of the haul-out period, during midday and during good weather conditions, but even then only about $70 \%$ or fewer of the seals may be on top of the ice (Finley, 1979).

Ringed seals are conspicuous on the ice and it is unlikely that many are missed by competent observers in an aircraft. However, the right front observer in the Twin Otter aircraft has considerable forward-scanning advantage over observers in rear seats. Thus, seals that dive in front of the aircraft or those in the narrow blind strip beneath the aircraft are probably missed by the rear observers. In 1978 and 1979 at $90 \mathrm{~m}$ elevation, the front and rear observers recorded 1260 and 639 seals, respectively - a ratio of 1.97:1.

\section{Specimen Collections}

We accompanied Inuit who shot ringed seals on fast ice within $10 \mathrm{~km}$ of the community of Pond Inlet $(n=12)$ and on pack ice $65-130 \mathrm{~km}$ off NE Baffin Island ( $n=45$ ) (Fig. 1). Transport to the pack ice was by helicopter. Most (10 of 12) of the fast-ice seals were taken between 8 and 13 June, and all pack-ice seals were taken between 23 June and 7 July. The hunters used white screens to approach basking seals and attempted to take every seal that was encountered (i.e. no apparent selectivity was exercised). Since pups shed their neonatal coat by May they were not well represented among the moulting seals in late June and early July.

\section{Morphometrics}

Body measurements included straight-line body length, axillary and maximum girth, and blubber thickness over the sternum. With the exception of body length these measurements conform with the recommendations of the American Society of Mammalogists (1967). Body length was determined by the criteria used by McLaren (1958a) and Usher and Church (1969). Eleven features were measured from skulls of all adult seals; ten additional features were measured from skulls of adult males. Cranial measurements were made according to the procedure illustrated by Timoshenko (1975). Only adult seals, eight years of age and older, were used in morphometric analyses; at this age they have achieved most of their final body length (McLaren, 1958a). Measurements were made with dial calipers read to $0.1 \mathrm{~mm}$. Student's $t$ tests were used to compare body length, girth and skull measurements of fastice and pack-ice seals.

\section{Age Determination}

Lower jaws were kept frozen until they were boiled in the laboratory for approximately $1 \mathrm{~h}$ to facilitate the extraction of the canine teeth. Thin cross-sections (0.2-0.3 mm) of the extracted canines were cut about one third of the distance from the root end to the crown. Extracted teeth and the thin sections were stored in ethanol and glycerine. Dentinal annuli were counted using a $20 \mathrm{X}$ binocular microscope, usually under transmitted light, following McLaren (1958a) and. Smith (1973). Each section was read by one of us (GWM) in blind replicates, i.e. with no knowledge of previous estimates, until two identical readings were obtained or until three estimates had been made. When no two of the three readings were identical, mean age was calculated and rounded to the nearest integer. All seals were aged to their most recent birthday, i.e. April. In 29 of 57 examples (51\%), age readings 1 and 2 were identical, and in 18 of the other 28 cases, reading 3 was identical to one of the two previous readings.

\section{Enzyme Electrophoresis}

Tissue samples from the heart, liver, kidney and muscle were cooled in ice and frozen within $24 \mathrm{~h}$ of collection. To assess genetic variability in seals from pack ice $(n=45)$ and fast ice $(n=12$ ), tissue samples were examined by J. Bogart 
and D. Lavigne, University of Guelph, using horizontal starch-gel electrophoresis (methods as in Lavigne et al., in press). They examined 27 genetic loci from 16 enzyme systems: two acid phosphatase loci; adenylate kinase; $\alpha$-glycerophosphate dehydrogenase; two general protein loci; two glutamate oxaloacetic transaminase loci; two isocitrate dehydrogenase loci; two lactate dehydrogenase loci; malic enzyme; two malate dehydrogenase loci; 6-phosphogluconate dehydrogenase; three superoxide dismutase loci; four phosphoglucose mutase loci; one sorbitol dehydrogenase locus; aconitase; esterase; and a glucose-6-phosphate dehydrogenase locus.

\section{Reproductive Condition}

Female reproductive tracts were preserved in $10 \%$ formalin. In the laboratory, uterine cornua were opened and examined for the remains of placental material from a recent pregnancy. Ovaries were cut in 1-mm slices and examined macroscopically for corpora lutea and albicantia.

\section{Pelage and Moult}

In the field, seals were examined for evidence of skin (epidermal) and hair moult and the skins were photographed. Strips of skin $(4 \times 8 \mathrm{~cm}$ ) were taken from the mid-dorsal area of seals collected in July and these samples were later examin ed under a $10 \mathrm{X}$ microsope. Old hair was easily distinguishable from developing hair by its dull, yellowish appearance. Hair growth was measured from small clumps of hair plucked from the skin. Developing, non-erupted hairs were measured in cross-sections of the epidermis. The epidermis was examined for evidence of sloughing.

\section{Diet and Stomach Parasites}

Food items from stomachs and faecal material from colons were collected and frozen. Later, thawed stomach contents and faecal material were weighed and then diluted with water in a shallow tray. The various constituents were separated through differential specific gravity (i.e. panning). Fish otoliths were identified and counted. Crustacean parts were examined under a low-power microscope and an estimate was made of the species composition on a percentage basis.

Seal stomachs were examined for nematodes. Clumps of nematodes on the stomach wall were classified as major $(>10$ individuals) or minor ( $<10$ individuals); major and minor clumps and all individually attached nematodes were counted.

\section{RESULTS}

\section{Distribution and Abundance}

Small numbers of ringed seals were seen during surveys in May but the peak of haul-out in both offshore and coastal areas occurred during the latter half of June and into early July. Group sizes of seals were similar in offshore and coastal areas, although they tended to increase in size from May to the peak

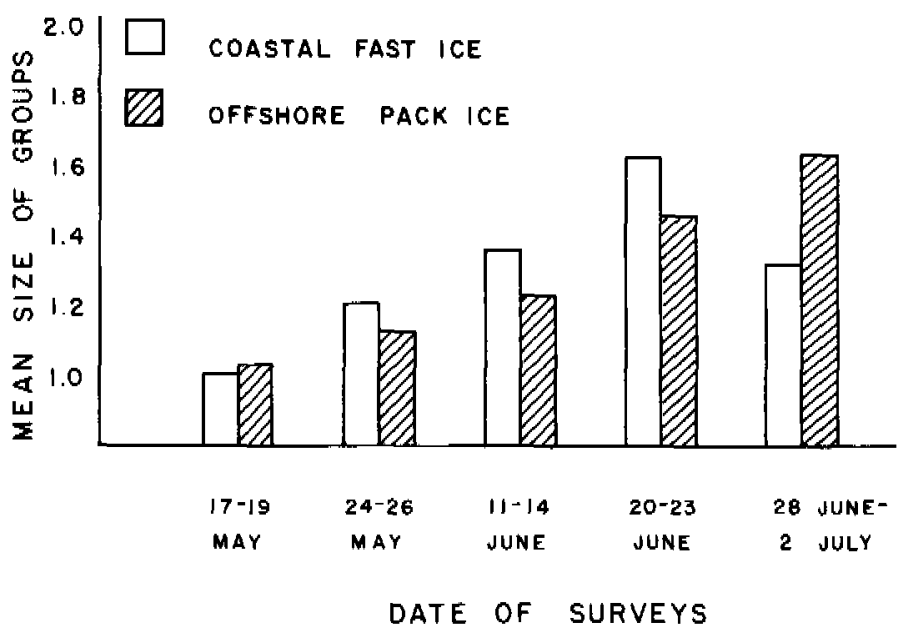

FIG. 3. Group sizes of ringed seals observed on coastal fast ice and offshore pack ice, 17 May-2 July 1979.

of haul-out (Fig. 3). There were no discernible shifts in the population from offshore to coastal areas or vice versa during the surveys.

Ringed seals were distributed throughout the offshore pack ice and the coastal fast ice of NW Baffin Bay (Fig. 1). Few seals were seen in peripheral areas of the pack-ice fields where the ice was more active and broken. Within the pack-ice fields densities tended to be rather uniform; a series of transects at 90 $m$ elevation conducted during the peak of haul-out in 1979 provided an overall density of 1.39 seals $\cdot \mathrm{km}^{-2}$. This was similar to the density ( 1.31 seals $\mathrm{km}^{-2}$ ) found on the coastal shelf during the same period (Table 1). Densities of seals in fiords in 1978 were variable $\left(0.86-3.20\right.$ seals $\left.\cdot \mathrm{km}^{-2}\right)$ but the overall mean density $\left(1.72 \cdot \mathrm{km}^{-2}\right)$ was somewhat higher than that for shelf ice and offshore pack ice in 1979 (Table 1).

TABLE 1. Densities of ringed seals on various ice types in NW Baffin Bay during the period of peak haul-out, 1978-79

\begin{tabular}{|c|c|c|c|c|}
\hline Ice Type & Area" & Date & $\begin{array}{c}\text { Area } \\
\text { Surveyed } \\
\left(\mathrm{km}^{2}\right)\end{array}$ & $\begin{array}{c}\text { Seal } \\
\text { Density } \\
\left(\mathrm{km}^{-2}\right)\end{array}$ \\
\hline Pack ice & Baffin Bay & 2 July 1979 & 606 & 1.39 \\
\hline $\begin{array}{l}\text { Fast ice } \\
\text { (Shelf) }\end{array}$ & NW Baffin I. & 20,21 June 1979 & 341 & 1.31 \\
\hline Fast ice & Coutts Inlet & 25 June 1978 & 121 & 2.46 \\
\hline \multirow[t]{5}{*}{ (Fiord) } & Buchan Gulf & 25 June 1978 & 97 & 3.20 \\
\hline & Scott Inlet & 25 June 1978 & 133 & 1.47 \\
\hline & Eclipse Sound & 22 June 1978 & 128 & 0.96 \\
\hline & Pond Inlet & 26,30 June 1978 & 118 & 0.86 \\
\hline & All fiords & 22-30 June 1978 & 597 & 1.72 \\
\hline
\end{tabular}

aFor areas covered see Fig. 1.

Application of these raw density estimates to the total area of pack ice in Baffin Bay and the bordering fast ice between Cape Dyer and Navy Board Inlet indicates that the pack ice of Baffin Bay supports a substantially larger population of seals than 
does the bordering fast ice along the east coast of Baffin Island. We estimate that the pack ice was inhabited by at least 417000 seals in late June-early July 1979 , whereas the fast ice was inhabited by at least 67000 seals. These are underestimates since they do not account for seals missed by the left rear observer and seals that were not hauled out during the surveys. Application of correction factors would increase the population estimate for the Baffin Bay pack ice to 550000 seals, if we allow for reduced efficiency of left rear observers, and to 787000 seals if we also consider that roughly $30 \%$ (Finley, 1979) of the total number of seals may not have been hauled out during the surveys.

Ringed seals apparently abandon offshore Baffin Bay after the ice disappears in late summer. Few ringed seals were seen during low-level surveys during August and September of 1978 and 1979 (details in Koski, 1980; Koski and Davis, 1979,1980 ). Seals are not easy to detect in rough water, but some offshore surveys were flown during calm conditions when seals could have easily been detected at the surface. For example, on 11 September 1979, mirror calm conditions prevailed over Baffin Bay, and during $292 \mathrm{~km}$ of offshore survey no seals were seen. Most ringed seals observed during aerial surveys in late summer were found in coastal waters. During many hunting trips by boat in Eclipse Sound in August and September we encountered ringed seals, sometimes in considerable concentrations (e.g., KJF counted at least 80 ringed seals within a $1-\mathrm{km}$ radius of a stationary boat in Eclipse Sound on 27 August 1978).

\section{Age Distribution and Reproductive Status}

Both the samples (45 pack-ice seals and 12 fast-ice seals) exhibited a similar age range of adult and immature seals, indicating that both samples were drawn from a breeding population (Fig. 4). Young-of-the-year and one-year-old seals were not represented in either sample; this was expected for the young-of-the-year seals but not necessarily for the one-year-
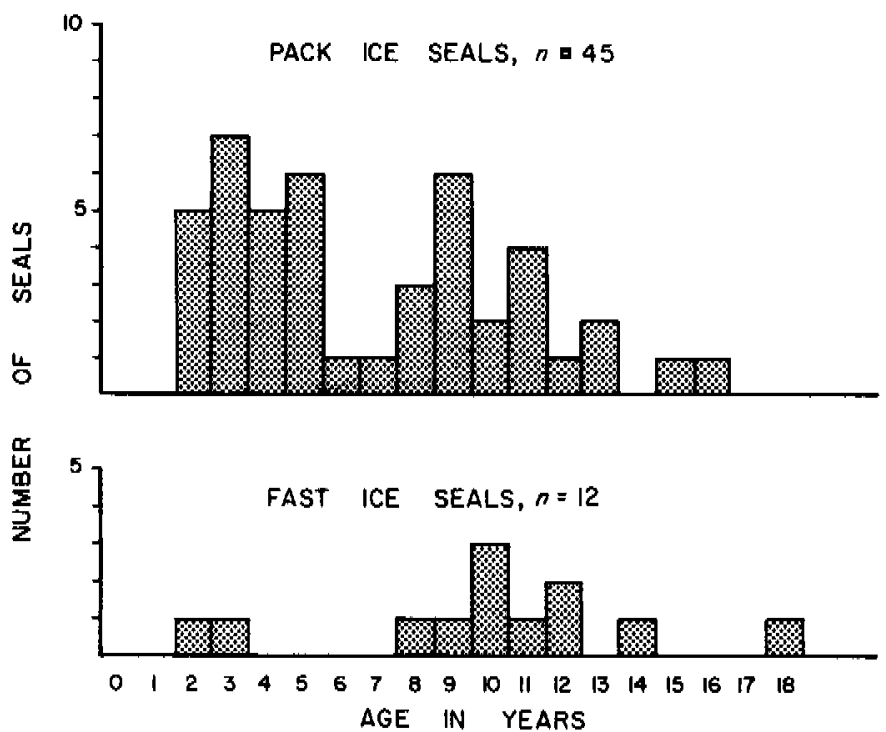

FIG. 4. Age distribution of ringed seals collected on pack ice and fast ice, JuneJuly 1979. olds, which would be expected to moult with older seals. We did observe small seals swimming in leads among the ice pans, and the aerial observers saw adults with pups on the pack ice in May.

Of the 45 pack-ice seals, 27 were females, of which 14 were sexually mature (Table 2 ). All females $>5 \mathrm{yr}$ old from both the pack ice and the fast ice had ovulated (corpus luteum present) during the most recent breeding season (April-May), but were taken during the period of delayed implantation, when embryos are not detectable. All these females also retained at least one corpus albicans from a previous ovulation. The uterine cornua of these individuals were thick and heavily vascularized with longitudinal foldings (quite distinct from the small, smooth cornua of immature specimens), indicating that these females had been pregnant in previous years.

TABLE 2. Reproductive condition of female ringed seals collected on pack ice and fast ice.

\begin{tabular}{|c|c|c|c|c|}
\hline Age & $n$ & $\begin{array}{c}\text { No } \\
\text { ovulation }\end{array}$ & $\begin{array}{c}\text { First } \\
\text { ovulation }\end{array}$ & $\begin{array}{c}\text { Previously } \\
\text { pregnant }\end{array}$ \\
\hline \multicolumn{5}{|c|}{ Pack Ice } \\
\hline 2 & 4 & 4 & - & - \\
\hline 3 & 5 & 5 & - & - \\
\hline 4 & 4 & 1 & 3 & - \\
\hline 5 & 3 & 3 & - & - \\
\hline \multirow[t]{2}{*}{$8-15$} & 11 & - & - & 11 \\
\hline & 27 & 13 & 3 & 11 \\
\hline \multicolumn{5}{|c|}{ Fast Ice } \\
\hline 2 & 1 & 1 & - & - \\
\hline \multirow[t]{2}{*}{$8-12$} & 5 & - & - & 5 \\
\hline & 6 & 1 & 0 & 5 \\
\hline
\end{tabular}

An indication of recent pregnancy was the presence in some uteri of orange stains on the inner wall of a cornus whose ovary contained a corpus albicans. We believe that these stains form at the site of placental attachment on the endometrial lining. This feature was observed in five of eleven of the parous pack-ice females and in four of five of the parous fast-ice females. The earlier collection dates of the fast-ice females may account in part for the greater frequency of this feature in those seals.

Our data are too limited to indicate anything conclusive about the age of sexual maturity; however, it is noteworthy that of the 4-yr-old pack-ice females, three out of four had ovulated (Table 2).

\section{Morphometry}

Male ringed seals ( $\geq 8 \mathrm{yr}$ old) from the pack ice were significantly smaller in length and girth than males from the fast ice (Table 3). Average estimated weights (calculated by the method of Usher and Church, 1969) of pack-ice and fast-ice males were 51.4 and $72.8 \mathrm{~kg}$, respectively. Female ringed seals from the pack ice were also significantly shorter $(t=$ $2.82, p<0.05)$ in body length than fast-ice females $(116.4 \mathrm{~cm}$ $+\operatorname{SD} 6.67, n=11$ vs. $126.2 \mathrm{~cm}+\operatorname{SD} 5.40, n=5$ ).

Pack-ice males were significantly smaller than fast-ice males 
TABLE 3. Body and cranial measurements of adult ( $\geq 8$ years old) males from the fast ice and pack ice"

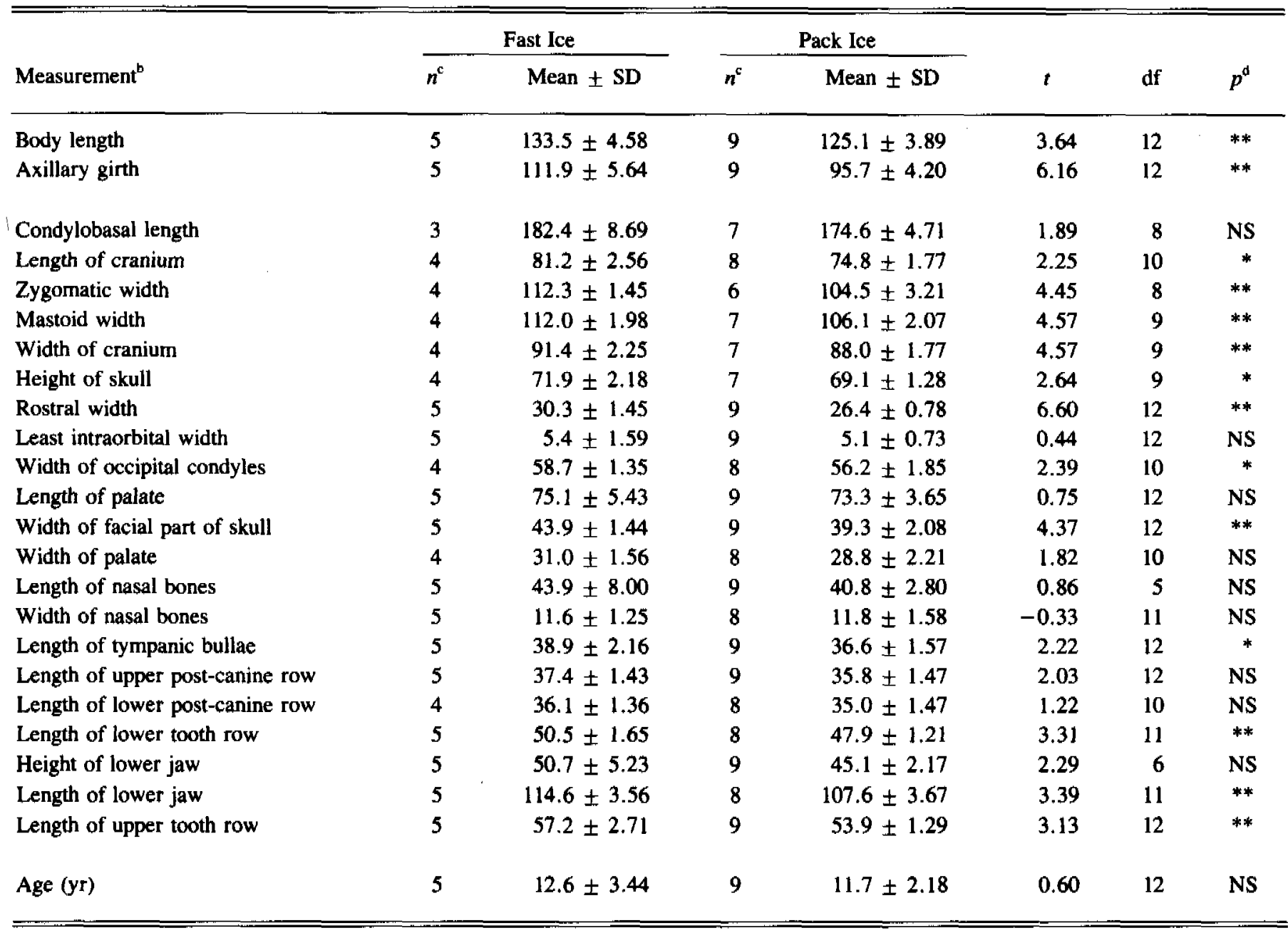

a All skull specimens have been deposited in the National Museum, Ottawa, catalogue numbers NMC 45419-NMC 45469.

${ }^{b}$ Body measurement in $\mathrm{cm}$, cranial measurements in $\mathrm{mm}$.

'Sample sizes were incomplete for some skull features that were damaged during collection.

${ }^{\mathrm{j}} \mathrm{NS}$, not significant; ${ }^{*}, p<0.05 ;{ }^{* *}, p<0.01$.

in 12 of 21 cranial features (Table 3 ). In general, the skulls of fast-ice males appeared more robust than those of the pack-ice males (Fig. 5). Females from the pack ice also averaged smaller in all cranial measurements but our sample sizes were too small for statistical treatment.

We plotted skull measurements $v s$. age for seals $\geq 8 \mathrm{yr}$ old to assess whether age-related biases occur in these older seals. Examples of these plots are presented in Figure 6. The size differences between the two groups are consistent across the age span of the animals examined and there is little or no overlap in most measurements.

\section{Genetic Variability}

Of 27 genetic loci from 16 metabolic enzymes, $24(88.9 \%)$ were monomorphic and demonstrated no variation. Variability was encountered for aconitase, one esterase locus, and a glucose-6-phosphate dehydrogenase locus, but the apparent variability was low and was not statistically different between the pack-ice and fast-ice seals. Low variability has also been found in the same enzyme systems examined for the harp seal (Phoca groenlandica) (Lavigne et al., in press).

\section{Pelage and Moult}

Although the colouration and markings of the ringed seals varied considerably, we could not discern any consistent differences in the pelage of the pack-ice and fast-ice seals. Fedoseev (1975) identified two pelage types and noted that one type was more predominant in Okhotsk ringed seals than in seals in Bering Strait and the Chukchi Sea.

Only two of ten fast-ice seals taken between 6-12 June showed any epidermal moult. Between 23-30 June epidermal moult was evident in eight of nine pack-ice seals. All seals re- 


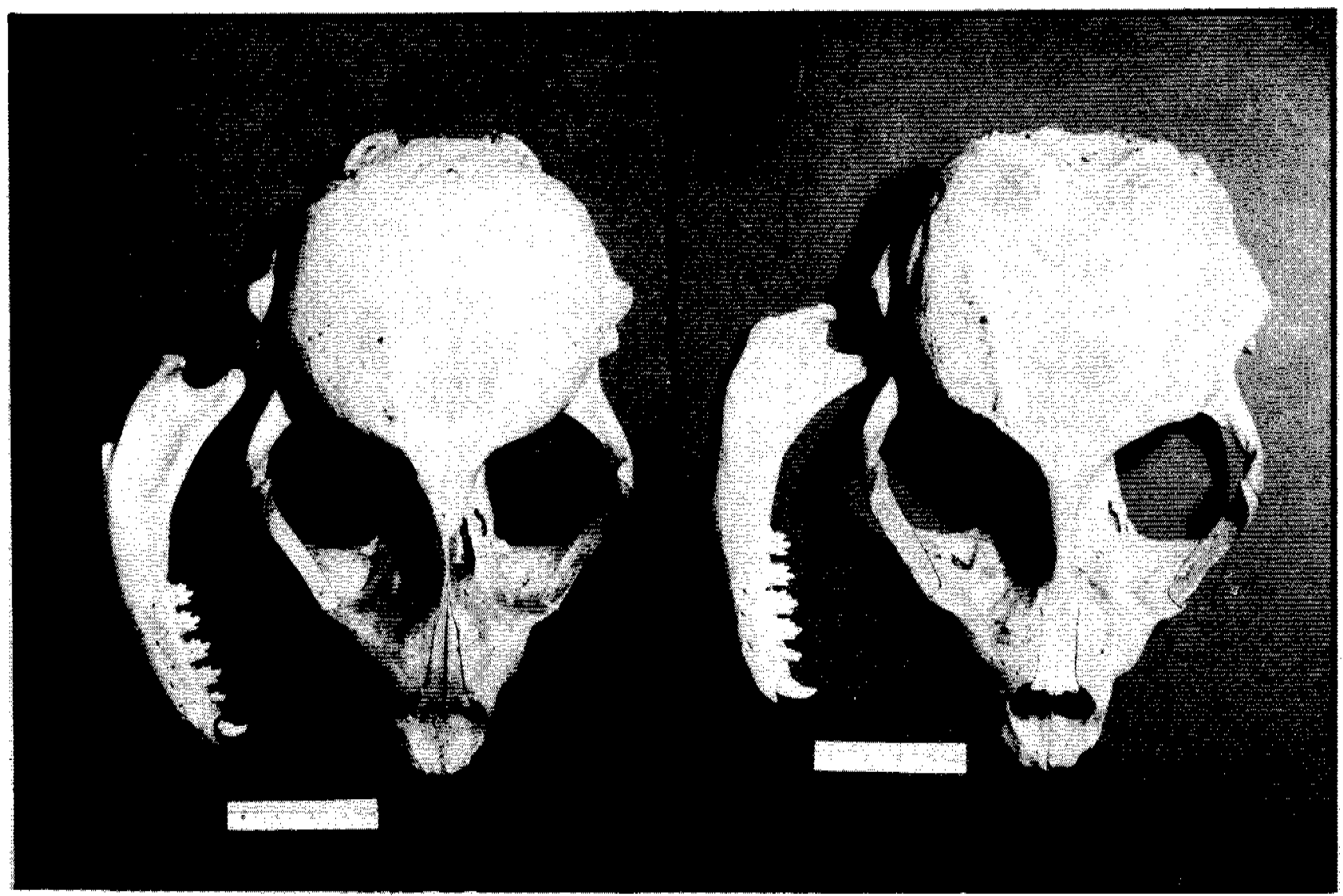

FIG. 5. Skulls and lower jaws of 10-yr-old male ringed seals from the pack ice (left) and the fast ice (right). Note the generally more robust appearance of the skull of the fast-ice seal.
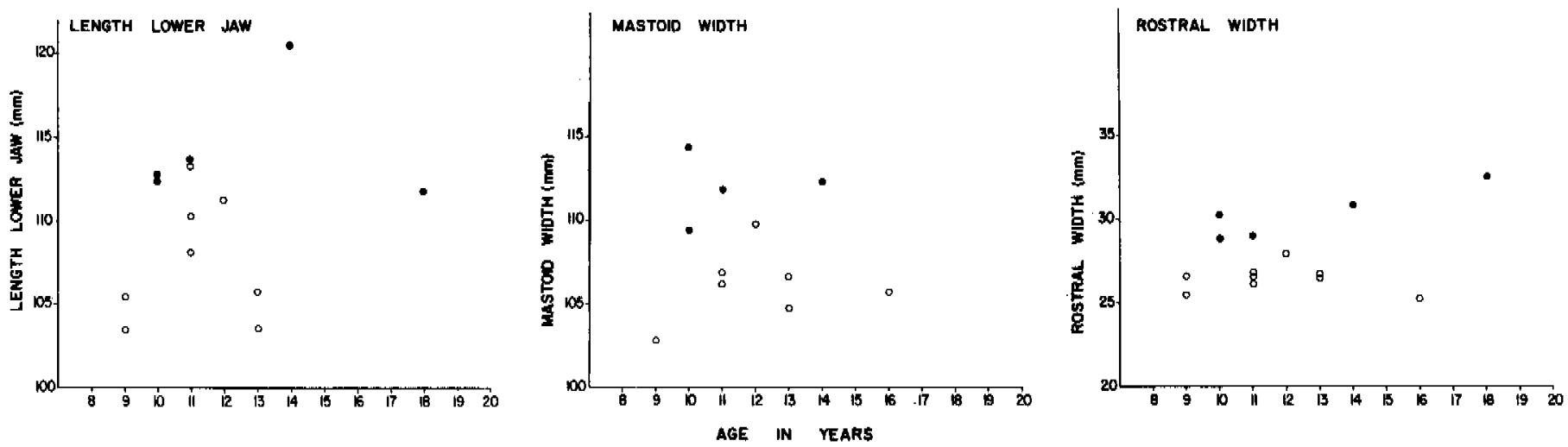

FIG. 6. Age-related comparisons of three cranial measurements of pack-ice $(0)$ and fast-ice ( $)$ seals.

tained their old pelage in June, though by late June it was noticeably looser.

Hair and epidermis in 25 skin samples from pack-ice seals collected during 1-7 July were in various stages of moult, ranging from one animal which had not begun to moult to two in which moult was complete (all old hairs had been shed) (Fig. 7). On most seals new hairs showed early stages of development and epidermal moult was well advanced. Apparently epidermal moult begins before new hairs erupt and is complete when new hairs are about $8 \mathrm{~mm}$ long. Old hair does not moult until after mid-July when the new hairs are nearly full length. The pattern and timing of moult appeared similar for both fast-ice and pack-ice seals.

\section{Diet}

More pack-ice seal stomachs (18 of 44) than fast-ice seal stomachs ( 1 of 12$)$ contained food items $\left(\chi^{2}=4.46, d f=1\right.$, 


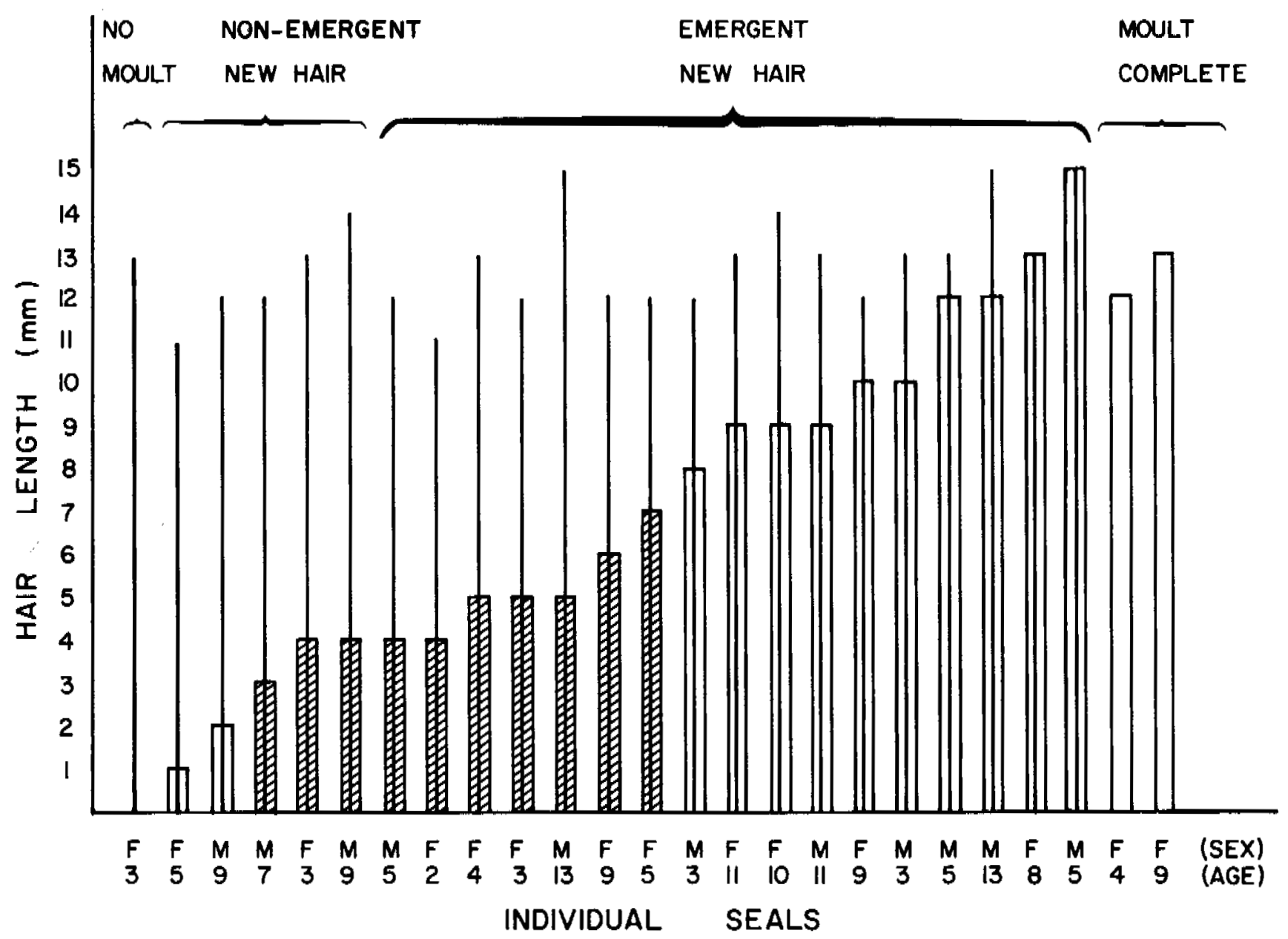

FIG. 7. Stages of hair and epidermal moult of ringed seals collected on offshore pack ice, 1-7 July 1979. Old hair is represented by solid lines and new hair by bars. Hatched bars represent individuals that were undergoing epidermal moult.

$p<0.05$ ). The amphipod Parathemisto libellula was found in all 18 pack-ice seal stomachs that contained food. $P$. libellula comprised $95-100 \%$ of the contents of these stomachs and was the only organism present in 14 of the stomachs. Some fish otoliths, primarily seasnails (Cyclopteridae), and a single mysid were the only other food items found. Analysis of faecal matter collected from 39 pack-ice seals also demonstrated the prevalence of $P$. libellula in the diet. Fish otoliths, primarily seasnails, were found more frequently $(77 \%)$ in faecal samples than in stomach contents $(22 \%)$, but usually occurred in small numbers.

\section{Stomach Parasitism}

The stomachs of pack-ice seals were notably less parasitized than were those of fast-ice seals. Nematodes were present in $10(91 \%)$ of 11 fast-ice seal stomachs but in only $6(14 \%)$ of 44 pack-ice seal stomachs $\left(\chi^{2}=25.5 ; d f=1, p<0.001\right)$. Also, the stomachs of pack-ice seals that did contain nematodes were less parasitized than were the stomachs of the fastice seals: most of the fast-ice seals but none of the pack-ice seals contained major clumps of nematodes imbedded in lesions of the stomach wall. An index of the number of nematodes in stomachs of infested seals was significantly lower for pack-ice seals (mean 4.0 \pm SD 2.8, $n=6$ ) than for fast-ice seals $(25.4 \pm 18.8, n=10$, Mann-Whitney $\mathrm{U}=7$, $p<0.02$ ).

\section{DISCUSSION}

Pack ice covers Baffin Bay for more than nine months of the year; both extent and timing are predictable. This platform provides both stable breeding habitat and access to pelagic areas that would otherwise be unavailable to the seals. By its dynamic and transitory nature the pack ice imposes a unique set of living conditions quite different from the fast ice.

\section{Offshore Distribution and Abundance}

Our surveys demonstrate that ringed seals are widely and fairly evenly distributed throughout the Baffin Bay pack ice from May through early July. Maintaining this even distribution would require that the seals undertake northward movements, since the pack ice generally flows south in western Baffin Bay throughout winter. The seals presumably 
occupy the pack ice when it forms in October and November, and pupping occurs when ice conditions are most stable in March-April. In June and July we noted that the seals and their holes were almost always along refrozen cracks or leads where ice thickness seldom exceeded $50 \mathrm{~cm}$. Unlike seals of the fast ice, which must maintain breathing holes in solid ice up to $2 \mathrm{~m}$ thick, pack-ice seals can occupy thin ice that continually forms during winter and thus probably need not maintain and defend one breathing hole (or small groups of holes) throughout the winter.

For purposes of rough estimates of the ringed seal population around Baffin Island, McLaren (1961, 1966a) and Smith (1973) depicted offshore areas as nearly devoid of seals. In fact, densities of seals in offshore Baffin Bay do not appear to be markedly different from densities in coastal areas. Our coverage of the offshore pack ice with 90-m surveys amounted to only $0.2 \%$ during the peak of haul-out, which is inadequate to attempt a realistic estimate of the pack-ice ringed seal population. However, we are confident, based on extensive coverage at $45 \mathrm{~m}$, that several hundred thousand ringed seals occupy the pack ice, and certainly the pack ice supports a much larger population of seals than does the bordering area of fast ice.

\section{Breeding Status}

Previous studies in coastal Baffin Island have found that floe edges and areas of unstable ice are occupied primarily by immature and non-breeding ringed seals (McLaren, 1958a; Smith, 1973). Miller and Finley (1982) also found that the floe edge is occupied by a high percentage of failed breeders and immatures. Our samples from much farther offshore indicate that many of the offshore seals are breeding animals. Although the sample size is small, the age structure of the offshore seals approximates that of a normal breeding population (cf. composite life table in Smith, 1973:44). All females $\geq 8 \mathrm{yr}$ showed evidence of recent and past reproductive activity. Fedoseev (1975) suggested that the age of first breeding in ringed seals on the pack ice of the Sea of Okhotsk was lower than in areas of fast ice in the Bering Sea, but his data on this are equivocal. Our sample from Baffin Bay is too small to determine the average age of first breeding, although it may be of interest that three of four 4-yr-old females had ovulated. Generally most females do not ovulate until their fifth or sixth year (see review by Davis et al., 1980). Fedoseev (1975) also stated that the lactation period for seals on the pack ice was only three weeks compared to the more normal six weeks on fast ice, but we have no data from Baffin Bay. There is no reason to suspect that ice stability would greatly affect the duration of lactation since the pack ice was stable well into June; the aerial observers saw pups in close association with adults on the pack ice in May and June.

\section{Population Discreteness}

Inuit hunters from northern Baffin Island recognize two distinct types of ringed seals; one of these, the pulajuraaq, is described as a small seal that enters the fiords after ice disperses in summer and leaves during freeze-up to occupy offshore areas. [Pulajuraaq is a syllabic transliteration of the north Baffin Inuktitut dialect. Phonetically it would appear as poo lá ù raá. The fiord seal is distinguished as tuvamiutaaq. A resident of Cumberland Sound (Pangnirtung) referred to the offshore seals as pulaniit.] Inuit of NW Greenland also distinguish between ringed seals of fiords and those from offshore areas (Vibe, 1950:77). McLaren (1958a:64) noted that Inuit of south Baffin Island were "convinced, through observation, that the 'bay-ice seals' average larger regardless of age"; however, he believed that size differences were related to ice stability (i.e. larger pups were produced on stable coastal ice and smaller non-breeding seals were excluded from this habitat). Our measurements indicate that ringed seals from the Baffin Bay pack ice are smaller than those from nearby coastal fast ice, which agrees with the observations of Inuit hunters. Fedoseev (1975) also found that ringed seals from the "drift ice" were smaller than those from coastal fast ice.

The relationship of the pack-ice seals to the fast-ice seals in Baffin Bay is unclear. Fedoseev (1975) suggests that the pack ice "ecotype" is a genotypic expression of the specific environmental influences of a pack-ice existence. Evidence of such a genotypic response to pack-ice breeding has been shown in the spotted seal Phoca largha. The largha seal of the Bering Sea was long thought to be an ice-adapted variant of the coastal harbour seal (Phoca vitulina), but it was recently accorded species status on the basis of morphological, behavioural and ecological evidence (McLaren, 1966b; Shaughnessy and Fay, 1977). Biochemical analyses were inconclusive in demonstrating genetic distinctiveness between the two species (Shaughnessy, 1975). Given the overall low genetic polymorphism among phocid seals (Lavigne et al., in press; J.P. Bogart, D.M. Lavigne, and R.G. Danzmann, pers. comm. 1982), and the fact that (limited) enzyme electrophoresis was unable to demonstrate genetic differences even between ice-breeding Phoca largha and land-breeding $P$. vitulina (Shaughnessy, 1975), it is not surprising that we found no difference between the pack-ice and fast-ice ringed seals of Baffin Bay.

The marked differences in the gut parasite load of pack-ice and fast-ice seals suggests quite different feeding regimes for the two populations. Delyamure (1955) stated that the helminth fauna of the Okhotsk ringed seal differed quantitatively and qualitatively from that of the coastal population, which had a much richer helminth fauna. In fact, the nematode Terranova skrjabini was said to be unique to the Okhotsk ringed seals. Unfortunately, few nematodes were properly preserved for identification in our study; several specimens from three stomachs of fast-ice seals were Contracaecum sp., while specimens from the stomachs of pack-ice seals were Terranova sp.

Our data suggest that the pelagic amphipod Parathemisto libellula is important to pack-ice seals, whereas ringed seals from coastal NE Baffin Island feed primarily on arctic cod throughout the year (Finley, pers. obs.). Fedoseev (1975) also observed that Okhotsk seals fed primarily on a pelagic 
euphausiid in contrast to the fish diet of coastal ringed seals. K. Frost (pers. comm. 1982) notes that "a difference in diet, which is almost assuredly a reflection of different prey availability, will account for a different parasite load" and that "in general, fish eaters have more parasites than crustacean eaters because fish are usually the final intermediate host."

The question of genetic distinctiveness of the pack-ice ringed seals in Baffin Bay may be resolved through further studies, but for now, it is prudent to recognize the existence of a large and distinctive pack-ice population. This has important management implications.

\section{Management Implications}

Ringed seals are the primary renewable resource for Inuit on both sides of Baffin Bay (McLaren, 1958b, 1961, 1962; Vibe, 1950; Bissett, 1967; Haller et al., 1967; Smith, 1973; Kapel, 1975; Treude, 1977; Wenzel, 1978; Davis et al., 1980; Finley and Miller, 1980). In Greenland, catches of ringed seals have averaged 50 000-70000 per year with an increasing trend, and although there is no knowledge of the population size, it is believed "that the stocks of ringed seals in Greenland are not threatened by hunting"' (Kapel and Petersen, 1982). The annual harvest of ringed seals by hunters from Broughton Island, Clyde and Pond Inlet is between 12000 and 15000 (Davis et al., 1980; Finley and Miller, 1980). Allowing for hunting losses, Miller et al. (1982) estimated that about 17300 seals are killed annually in this area. Our uncorrected estimate of the number of ringed seals occupying coastal fast ice from Cape Dyer to Navy Board Inlet was about 67000 . When we correct for differential visibility and conservatively assume that half the seals were under the ice during the surveys, then the estimate is about 177000 seals. If the sustainable yield of the population is $7 \%$ (Smith, 1973), then 250000 seals would be necessary to support an annual kill of 17300 . Obviously this kill cannot be supported by the fast-ice population alone. Yet there is no evidence that coastal populations of ringed seals are declining; present harvest levels appear to have been maintained for many years (Finley and Miller, 1980). Therefore it is highly probable that a considerable portion of the annual harvest comes from the pack-ice population. The limited fast ice in West Greenland suggests that much of the harvest there must also consist of pack-ice seals (Miller et al., 1982).

In $1979,37-39 \%$ of the ringed seal catches at Pond Inlet and Clyde were taken during the open-water season (Finley and Miller, 1980) when the pulajuraaq are said to enter the fiords. It may eventually be possible to estimate the proportion of pack-ice seals in coastal harvests by using morphometric analyses of jaws that have been collected from hunter kills. More systematic collections of pack-ice and fast-ice seals will be needed to verify this.

The present documentation of a previously unrecognized large population of ringed seals in Baffin Bay serves to demonstrate how little is known about the population dynamics of this species in the Canadian Arctic. Present knowledge, particularly of population sizes, is inadequate to assess the impact of increasing hunting pressure (Davis et al., 1980) or in- dustrial activities (Davis, 1981) on seal populations in the Canadian Arctic. By contrast, much more attention has been given to the management of the politically sensitive harp seal (Phoca groenlandica) hunt (Wenzel, 1978). In view of the cultural and economic importance of the ringed seal to Inuit (Bissett, 1967; Wenzel, 1978; Myers, 1982), at a time when populations of indigenous people are increasing at a rapid rate (Hamelin, 1979), this lack of knowledge is a significant impediment to proper management decisions. The situation is complicated by its international scope. It also has implications to the large population of polar bears (Ursus maritimus) that is dependent on the seals of the Baffin Bay pack ice. Management of ringed seals in the Baffin Bay region should, therefore, be international in scope and should consider the conflicting demands for seals by polar bears and by Inuit.

\section{ACKNOWLEDGEMENTS}

This research was funded by Petro-Canada Explorations as part of a multi-disciplinary research program, the Eastern Arctic Marine Environmental Studies (EAMES) program. We especially thank G. Glazier, G. Koenig, W. Speller and B. Veldhoen of Petro-Canada for their assistance and support.

This study could not have been accomplished without the assistance of the Pond Inlet hunters, particularly P. Aglak who taught us much. G. Sleno of the Arctic Biological Station, Ste. Anne de Bellevue, assisted in the preparation of tooth sections. D. Campbell of the National Museums of Canada, Ottawa, prepared the skulls and assisted in measurements. A. Sekerak of LGL Ltd. identified the stomach parasites and W.J. Richardson, as usual, kept us in line. K. Frost and 1. McLaren provided constructive comments on the manuscript. We are grateful to all of these people.

\section{REFERENCES}

AMERICAN SOCIETY OF MAMMALOGISTS. 1967. Standard measurements of seals. Journal of Mammalogy 48:459-462.

BISSETT, D. 1967. Northern Baffin Island: An Area Economic Survey. Vol. 2. A.E.S.R. 67/1. Ottawa: Department of Indian Affairs and Northern Development. $131 \mathrm{p}$.

BURNS, J.J., SHAPIRO, L.H. and FAY, F.H. 1981. Ice as marine mammal habitat in the Bering Sea. In: Hood, D.W. and Calder, J.A. (eds.). The Eastern Bering Sea Shelf: Oceanography and Resources. Office of Marine Pollution Assessment, NOAA, Seattle. 781-797.

COLLIN, A.E. and DUNBAR, M.J. 1964. Physical oceanography in Arctic Canada. Oceanography and Marine Biology Annual Review 2:45-75.

DAVIS, R.A. 1981 . Report of a workshop on arctic marine mammals. Canadian Technical Report of Fisheries and Aquatic Sciences No. 1005.13 p.

, FINLEY, K.J. and RICHARDSON, W.J. 1980. The present status and future management of arctic marine mammals in Canada. Yellowknife: Science Advisory Board of the Northwest Territories. Report No. 3. $93 \mathrm{p}$. 
DELYAMURE, S.L. 1955. Helminthofauna of marine mammals (ecology and phylogeny). Akademiya Nauk SSSR. (Israel Program for Scientific Translations, Jerusalem, 1968.)

FEDOSEEV, G.A. 1975. Ecotypes of the ringed seal (Pusa hispida Schreber, 1777 ) and their reproductive capabilities. In: Ronald, K. and Mansfield, A.W. (eds.). Biology of the Seal. Rapports et Proces-verbaux des Réunions, Conseil International pour L'Exploration de la Mer 169:156-160. and YABLOKOV, A.V. 1964. Morphological characteristics of the ringed seal (Pusa hispida, Pinnipedia, Mammalia) in the Okhotsk Sea, Zoologicheskii Zhurnal 44:759-765. (Summary in English.)

FINLEY, K.J. 1979. Haul-out behaviour and densities of ringed seals (Phoca hispida) in the Barrow Strait area, N.W.T. Canadian Journal of Zoology 57:1985-1997.

and MILLER, G.W. 1980. Wildlife harvest statistics from Clyde River, Grise Ford and Pond Inlet 1979. Unpubl. Rep. by LGL Ltd., Toronto, for Petro-Canada Exploration, Inc., Calgary. 37 p. [Available from Pallister Resource Management Ltd., Bay 105, 4116-64 Ave. S.E., Calgary, Alberta, Canada T2C 1P4.]

FISSEL, D.B., LEMON, D.D. and BIRCH, J.R. 1982. Major features of the summer near-surface circulation of western Baffin Bay, 1978 and 1979. Arctic 35:180-200.

HALLER, A., FOOTE, D. and COVE, P. 1967. The East Coast of Baffin Island: An Area Economic Survey. A.E.S.R. 66/4. Ottawa: Department of Indian Affairs and Northern Development. $196 \mathrm{p}$.

HAMELIN, L.-E. 1979. Contribution to the Northwest Territories population studies 1961-1985. Yellowknife: Science Advisory Board of the Northwest Territories. Report No. 1.54 p.

KAPEL, F.O. 1975. Recent research on seals and seal hunting in Greenland. In: Ronald, K. and Mansfield, A.W. (eds.). Biology of the Seal. Rapports et Proces-verbaux des Réunions, Conseil International pour L'Exploration de la Mer 169:462-478.

and PETERSEN, R. 1982. Subsistence hunting - the Greenland case. Report of the International Whaling Commission (special issue 4).

KOSKI, W.R. 1980. Distribution and migration of marine mammals in Baffin Bay and eastern Lancaster Sound, May-July 1979. Unpubl. Rep. by LGL Ltd., Toronto, for Petro-Canada Exploration, Inc., Calgary. 317 p. [Available from Pallister Resource Management Ltd., Bay 105, 4116-64 Ave. S.E., Calgary, Alberta, Canada T2C 1P4.]

and DAVIS, R.A. 1979. Distribution of marine mammals in northwest Baffin Bay and adjacent waters, May-October 1978. Unpubl. Rep. by LGL Ltd., Toronto, for Petro-Canada Exploration, Inc., Calgary. 305 p. [Available from Pallister Resource Management Ltd., Bay 105, 4116-64 Ave. S.E., Calgary, Alberta, Canada T2C 1P4.]

1980. Studies of the late summer distribution and fall migration of marine mammals in NW Baffin Bay and $E$ Lancaster Sound, 1979. Unpubl. Rep. by LGL Ldd., Toronto, for Petro-Canada Exploration, Inc., Calgary. 214 p. [Available from Pallister Resource Management Ltd., Bay 105, 4116-64 Ave. S.E., Calgary, Alberta, Canada T2C 1P4.]

LAVIGNE, D.M., BOGART, J.P., DOWNER, R.G., DANZMANN, R.G., BARCHARD., W.W., and EARLE, M. In press. Genetic uniformity in Northwest Atlantic harp seals, Pagophilus groenlandicus. In: Lavigne, D.M., Ronald, K. and Stewart, R.E.A. (eds.). The Harp Seal. Perspectives in Vertebrate Science. The Hague: Dr. W. Junk bv Publishers.

MARKHAM, A.H. 1874. Whaling cruise to Baffin's Bay and the Gulf of Boothia. London: Sampson Low, Marston, Low and Searle. $300 \mathrm{p}$.

McLAREN, I.A. 1958a. The biology of the ringed seal (Phoca hispida Schreber) in the eastern Canadian Arctic. Fisheries Research Board of Canada Bulletin 118. 97 p. 1958b. The economics of seals in the eastern Canadian Arctic. Fisheries Research Board of Canada Arctic Circular 1. 94 p.

1961. Methods of determining the numbers and availability of ringed seals in the eastern Canadian Arctic. Arctic 14:162-175.

1962. Population dynamics and exploitation of seals in the eastern Canadian Arctic. In: LeCren, E.D. and Holdgate, M.W. (eds.). The Exploitation of Natural Animal Populations. Oxford: Blackwell Scientific Publications. 168-183.

1966a. Analysis of an aerial census of ringed seals. Journal of the Fisheries Research Board of Canada 23:769-773.

1966b. Taxonomy of harbor seals of the western North Pacific and evolution of certain other hair seals. Journal of Mammalogy 47:466-473.

MILLER, G.W., DAVIS, R.A. and FINLEY, K.J. 1982. Ringed seals in the Baffin Bay region: habitat use, population dynamics and harvest levels. Unpubl. Rep. by LGL Ltd., Toronto, for Arctic Pilot Project, Calgary. 93 p. [Available from Arctic Pilot Project, 550-6th Avenue S.W., Calgary, Alberta, Canada T2P 0S2.]

MILLER, G.W, and FINLEY, K.J. 1982. Kill distribution, age and reproductive status of ringed seals (Phoca hispida) taken in three eastern Canadian arctic communities. Unpubl. Rep. by LGL Ltd., Totonto, for PetroCanada Exploration, Inc., Calgary. [Available from Pallister Resource Management Ltd., Bay 105, 4116 - 64 Ave. S.E., Calgary, Alberta, Canada T2C 1P4.]

MYERS, H. 1982. Traditional and modern sources of income in the Lancaster Sound region. Polar Record 21:11-22.

SHAUGHNESSY, P.D. 1975. Biochemical comparison of the harbour seals Phoca vitulina richardi and $P$, v, largha. In: Ronald, $\mathrm{K}$. and Mansfield, A.W. (eds.). Biology of the Seal. Rapports et Proces-verbaux des Réunions, Conseil International pour L'Exploration de la Mer 169:70-73.

and FAY, F.H. 1977. A review of the taxonomy and nomenclature of North Pacific harbour seals. Journal of Zoology 182:385-419.

SMITH, T.G. 1973. Population dynamics of the ringed seal in the Canadian eastern Arctic, Fisheries Research Board of Canada Bulletin 181.55 p.

1975. Ringed seals in James Bay and Hudson Bay: population estimates and catch statistics. Arctic 28:170-182.

and STIRLING, I. 1975. The breeding habitat of the ringed seal (Phoca hispida). The birth lair and associated structures. Canadian Journal of Zoology 53:1297-1305.

STIRLING, I. and SMITH, T.G. 1977. Interrelationships of Arctic Ocean mammals in the sea-ice habitat. In: Circumpolar Conference on Northern Ecology. Ottawa: National Research Council of Canada. 129-136.

SUTTERLIN, N, and SNOW, N. 1982. Introduction to the Eastern Arctic Marine Environmental Studies program. Arctic 35(1):iii-iv.

TIMOSHENKO, Y.K. 1975. Craniometric features of seals of the genus Pusa. In: Ronald, K. and Mansfield, A.W. (eds.). Biology of the Seal. Rapports et Proces-verbaux des Réunions, Conseil International pour L'Exploration de la Mer 169:161-164.

TREUDE, E. 1977. Pond Inlet, northern Baffin Island: the structure of an Eskimo resource area. Polar Geography 1:95-122.

USHER, P.J. and CHURCH, M. 1969. On the relationships of weight, length and girth of the ringed seal (Pusa hispida) of the Canadian Arctic. Arctic 22:120-129.

VIBE, C. 1950. The marine mammals and the marine fauna in the Thule District (northwest Greenland) with observations on ice conditions in 1939-41. Meddelelser om Gronland 150.117 p.

WENZEL, G. 1978. The harp seal controversy and the lnuit economy. Arctic 31(1):2-6. 